\title{
PROSPECTS AND PROBLEMS IN GIRLS SPORTS PARTICIPATION AT UNIVERSITY LEVEL IN KHYBER PAKHTUNKHWA, PAKISTAN
} Mohibullah Khan Marwat ${ }^{1 *}$, Afshan Jabeen ${ }^{2}$, Ismat Ullah ${ }^{3}$, Muhammad Shah ${ }^{4}$, Sofia Saba

${ }^{1 *}$ Department of Sports Sciences and Physical Education, Faculty of Allied Health Sciences, The University of Lahore, Lahore, Pakistan; ${ }^{2}$ Principal, Education Department Punjab, Pakistan; ${ }^{3}$ Ph.D., Scholar, Department of Sports Sciences and Physical Education, Faculty of Allied Health Sciences, The University of Lahore, Pakistan; ${ }^{4}$ Lecturer, Department of Physical Education and Sports, Abdul Wali Khan University Mardan (KPK), Pakistan; ${ }^{5}$ M.Sc., Zoology, Bio-Chemistry

Teacher at Bahria Foundation College, Bhara Kahu, Islamabad, Pakistan.

Email: ${ }^{1 *}$ mohibullah.khan@ed.uol.edu.pk, ${ }^{2}$ ajmalik54@gmail.com, ${ }^{3}$ mahrismat@gmail.com,

${ }^{4}$ muhammadshah@awkum.edu.pk, 5ufyan123khan@gmail.com

Article History: Received on $18^{\text {th }}$ June 2021, Revised on $25^{\text {th }}$ June 2021, Published on $29^{\text {th }}$ June 2021

\begin{abstract}
Purpose: Main objectives of this review paper were to examine the existing position regarding the religious perspectives in connection with female participation in sports, opportunities, and barriers affecting their entry into sporting activities. The focus of this article was to investigate the viewpoint of the female regarding the religious and socio-cultural factors influencing women's participation in sports.
\end{abstract}

Methodology: A self-made questionnaire consisting of twenty-four different items encircling religious and socio-cultural factors affecting women's participation in sports was used for the collection of data. Population for this study comprised of conveniently available 236 border girls students of Gomal University Dera Ismail Khan.

Main Findings: Findings of the study has revealed that, in addition to dominant religious trend and sociocultural environment, lack of facilities, law and order situation, and transportation issues in reaching the facility, dress code, misconception of the masses in perspectives of the female participation in sports and financial problems were the main barriers in the way of female participation in sports.

Implications: It is recommended that parents, teachers, religious leaders, experts in the field of health and sociology, and different sources of social media should play their role in clarifying the situation in paving the way for the female folk to bring positive change in the situation.

Keywords: Women, Religion, Girls, Sports, Barriers, Students.

\section{INTRODUCTION}

About the Muslim community, the role of religious and socio-cultural factors has always been dominant in perspectives of female participation in sports, particularly at the local, regional and elite levels. Looking back at the near past, it had been the religious and socio-cultural factors that mostly decided the fate of the female folk with regards to participation in the sports competition. As a matter of fact, in Muslim society, despite female participation in sports is encouraged rather efforts have been put forth to keep it confined to a limited level (Ahmed, 2017). Participation statistics especially in the Olympic Games illustrate a poor picture on part of the females from Muslim countries (International Olympic Committee, 2019). The trend of Muslim female participation in sports demonstrates a meager number in comparison to the Muslim population in the world. It has also been a part of the history of the female sport that women participants were omitted from the Olympic Games in 1896. Over time this approach changed steadily and women began to appear in the Olympic arena. In Berlin Olympics in 1936, pioneer women from Turkey represented their country at the Olympic Games in the event of Fencing (China Daily, 22 August 2008). Later on, in 1964, Iranian women represented their nation in the Tokyo Olympics in athletics and gymnastic (Rizvi \& Rio, 2016). Even though almost 20\% of the world's population is Muslim but we see that in the Beijing Olympic Games in 2008, only 02\% (98) of the female participants represented the Muslim nations from around the globe. In Los Angles Olympic Games in 1984, Nawel Moutawakel from Morocco became the ever first Muslim woman to win the gold medal at the elite-level sports competition. Only male teams from Kuwait, Qatar, and Saudi Arabia participated in the Beijing Olympic Games and for the first time, female teams from the United Arab Emirates and Oman participated in the Olympic Games (MOENT, 2017). Similarly, fourteen Muslim women achieved different medals in the diverse fields in the Rio de Janeiro 2016 Olympic Games (Harvard, 2016). Gradual improvement in the situation can be observed in this regard.

In views of Islamic teachings, "Healthy and fit Muslim is better than weak and ailing Muslim" (Sahih Muslim). Islam discourages idleness and promotes active and busy life, the ultimate product of which is sound health and overall fitness. In this regard, manual and practical work is always encouraged in Islam and, as endorsed by the Prophet Muhammad "Manual Worker is dear to God".

\section{LITERATURE REVIEW}

Religion provides a complete code of ethics and a proper way of leading a healthy and successful life. It encircles diverse characters and different aspects of one's life. Betterment and all-round success is the ultimate objective of the religious 
teachings. Islam is the religion of peace, fraternity, and tranquility. From religious perspectives, good health and fitness have got paramount significance.

\section{Religious Perspectives about Health and Fitness}

In views of Islamic teachings, "Healthy and fit Muslim is better than weak and ailing Muslim" (Sahih Muslim). Islam discourages idleness and promotes active and busy life, the ultimate product of which is sound health and overall fitness. In this regard, manual and practical work is always encouraged in Islam and, as endorsed by the Prophet Muhammad "Manual Worker is dear to God".

Health, working capacity, and fitness all are reflected and accommodated in the functioning of the human body. Tens of hundreds of tinny organs simultaneously remain at work inside the body. Regarding the vitality of the human body, Islamic teachings claim that "Your bodies have rights upon you". It signifies the vitality of the fit and energetic human body. Health is considered to be nothing less than a heavenly gift. "Health and prosperity are amongst the blessings of God" Islam claims. Islam has put stress upon the care and protection of the bodies and health. According to the saying of the Holy Prophet Muhammad "Serve your health before falling victim to any deformity or disease". In Islam, the sound health and fitness of the Muslims are always stressed for the personal as well as the collective benefit of the Muslim society. Islamic teachings advocate in favor of health and fitness and have declared for the Muslims to "Keep themselves healthy and fit to promptly combat the non-believers".

\section{Religious Perspectives about Women Participation in Sports}

The role and status of religion, particularly in the Muslim community, is very much significant. Justification, values, and worth of all actions and activities of the Muslims are evaluated, approved, and determined by the religious perspectives. The same is the case with female participation in sports in Muslim society. Islam has very scholarly addressed various issues related to the everyday life of the Muslims and workable guidance is given for the solution and coping with the problems. Since in Islam special code of life activities and social status exists for women, therefore, their participation in sports has been one of the hot debating topics amongst Muslim scholars. The issue of whether women should take part in sports activities or otherwise has been severally been discussed from different angles. Islamic teachings and sayings of the Holy Prophet Muhammad have framed a few guiding principles for female participation in sports and the female who comply with these Islamic principles may participate in sports. Concerning participation in sports, a common understanding among the Muslim communities is that females are required to be protected from being sighted by their male counterparts (Patrick Johnston, 2016). However, one thing is clear that, on account of having a special place in Islam, females have to obey several additional restrictions in the perspective of taking part in the sports competition (Ashraf et al, 2016).

The first and foremost Islamic principle related to the social life of Muslim women is the covering of the hair, face, and other parts of the body known as the "Hijaab". Muslim women use loose clothes and veils for this purpose so that their body parts are not exposed. Obedience to this principle begins with the start of puberty among Muslim girls. Following the principle of "Hijaab" is particularly meant for interaction with the male who is allowed to marry her (Non-Mehram). During sports activities when all the participants, viewers, and organizers are female, the competitors may carry on without "Hijaab" (Harvey, 2019).

The dress code is the next principle for Muslim women, which is required to be followed during the course of playing. The dress covering all parts of the body should be used during sports activities. Loose clothing is required to be used during sports competitions (Ahmed, 2017). Similarly, gambling is a prohibited activity in Islam and the next Islamic principle guides us about obeying this principle by avoiding the act of gambling in sports. As discussed earlier, the female has got a very honorable status in Islam therefore they are not allowed to openly interact with the male (NonMehram) counterpart. This principle refrains the Muslim women to hold joint playing sessions with the male participants and also play before the male (Non-Mehram). The last and final principle is associated with paying due attention to the basic responsibility of timely discharging the religious duty "Fard" by offering the obligatory five times Prayers.

Regarding participation in sports, the sound health and physical fitness level of the participant matter a lot. Participation in sports is an activity full of action requiring a healthy and energetic physique on part of the person taking part in the activity. Similarly, Islam asserts firmly in favor of health and physical fitness. Islam affirms that "Good health and prosperity are amongst the blessings of Almighty Allah". The same stance has been endorsed by Muhammad "I seek your protection from powerlessness (A-Z), laziness (KASL), cowardice (jubn), miserliness (BUKHL), and weakness (harem)" have been His common prayers; Sayyiduna Zayd ibn Arqam (RA) has reported. Abu Dawood has reported quoting Ayesha that two trials running competition were held between Muhammad and his wife Ayesha, the first trial was won by Ayesha and the second was won by him (Muhammad confirmed by Muhammad's races with his wife Aisha (MOENT. 2017). Complying the basic Islamic codes, participation in sports for enhancing the different capabilities of the body is supported by Islamic teachings (MOENT. 2017).

\section{Hurdles faced by the Muslim Women in their way to Participation in Sport}


There exist several socio-cultural, financial, and religious difficulties which dominantly affect Muslim women's participation in sports. Different schools of thought and different types of approaches are found in the masses of society concerning female participation in sports. The most common perception in the conservative segment of the society declares that participation in sports is Haram (Prohibited) for Muslim women. The nature and intensity of the problem regarding female participation in sports differ from time to time and locality to locality. However, research has concluded that Family, time, and financial constraints alongside scarcity of the playing infrastructure have been the most frequent hurdles in the way of female participation in sports (Lubans, \& Sylva, 2019). Muthuri, Wachira, Onywera \& Tremblay, (2019) have confirmed that personal security, gender discrimination, and the high cost of the facilities also affect female participation in sports.

Literature has concluded that the overall volume of female participation in sports is quite poorer in comparison to their male counterparts. The lower trend of participation in sports prevails among the female. Another aspect of concern in this regard is the household responsibilities on part of the female in the Muslim societies which refrain them from participation in sports (Dishman, Saunders, Dowda \& Pate, 2017). The poor financial status of the families and the dominant role of the male in deciding the financial matter of the house in the Muslim societies is another prominent hurdle preventing females from prompt participation in sports. Majority of the Muslim women have to rely upon the will, desire, and resources of their male counterparts and they have very limited or, in most cases, no authority to spend the earing of their male according to their desire and choice particularly in perspectives of participation in sports (Culpepper \& Chuck, 2016). Lenneis and Pfister (2017) have affirmed that for women's participation in sports, the role of financial status is vital in comparison to gender, age, and educational background. Kara and Demirci also support the same findings declaring that women from high financial backgrounds face no problem in their participation in sports.

In addition to the above, among true and conservative societies, Muslim female is confronted to many other problems posed by the socio-cultural setup of the community. Several socio-cultural hurdles impede the way of female participation in sports (Heaney \& Israel, 2018). Ashraf (2019) has summed up the detail of the common obstacles which limits Muslim female participation in include male-oriented society, domination of male in making the decisions, lack of proper opportunities for participation in sports, limited financial resources and social misconception in perspectives of female sports. Literature has confirmed that in comparison to males, females are more prone to different types of constraints in their way to participation (Ashraf, 2018).

\section{STATEMENT OF THE PROBLEM}

Prejudice, biased, injustice, discrimination, inequality, and intolerance are the different forms of human behavior and one can observe them in one way or the other in everyday life. Discrimination and inequality are the two main points of concern concerning women's participation in sports. The low level of female participation in sports is not because they are not interested in sports but they have always been subjected to different forms of socio-cultural and other issues in their way to participate in sports. History of the women participation in sports reflects the picture showing a very low level of participation in sports as compared to their male counterparts on account of several reasons including religious, socio-cultural, economic, gender and family factors. In addition to that, on account of the low rate of literacy, a general misconception also exists among the female folk concerning the utility of participation in sports for females. They generally consider sports as not useful for their wellbeing and future life. Available literature has confirmed the scarcity of research work focusing upon the religious and socio-cultural aspects regarding girls' participation in sports at the university level. This research study examined the aforementioned factors influencing women's participation in sports.

\section{OBJECTIVES OF THE STUDY}

1. To examine religious factors that affect the participation of girls in sports activities at the university level.

2. To determine socio-cultural factors affecting the participation of girls in sports activities at the university level.

\section{HYPOTHESES}

The following three hypotheses were formulated for this study:

$\mathbf{H}_{\mathbf{1}}$ : The religious factor will have a significant influence on girls' participation in sports among Gomal University students.

$\mathbf{H}_{2}$ : The socio-Cultural factor will have a significant influence on girls' participation in sports among Gomal University students.

\section{METHODOLOGY}

\section{Population}

The population for the study consisted of 750 border girls students residing in three different hostels of Gomal University Dera Ismail Khan (KP) Pakistan. These hostels were easily accessible for the researcher in connection with the collection of real and timely responses from the respondents. Out of the total population, the researcher took conveniently available 236 girls as the study sample population for this research work. 


\section{Sample}

The researcher took conveniently available 236 respondents as the study sample for this research work.

\section{Sampling Technique}

A purposive sampling technique was employed for the selection of the sample.

\section{Data Collection}

A descriptive research design was adopted for this study. Before the collection of data, consent and favor of the Deputy Provost Girls were obtained. The purpose and objective of the collection of data were briefed to the respondents and a self-made questionnaire was distributed among the respondents. The primary portion of the questionnaire consisted of the demographic information of the respondents whereas the second portion of the questionnaire was loaded with the different variables of the study including religious, socio-cultural, and family-related factors. Twenty-four different items encircling various aspects of the problem were used for the collection of data. The validity of the questionnaire was determined by the concerned experts in the field of sports sciences and reliability was confirmed according to a pilot study on 30 students obtained 0.83 as it is considered as the acceptable level of internal consistency of the measuring tool. The collected data were tabulated and analyzed accordingly using SPSS.

\section{ANALYSIS OF DATA}

Table 1: Showing Demographics- wise frequencies and percentages of respondents

\begin{tabular}{llll}
\hline Demographics & Category & Frequency & Percent \\
\hline \multirow{2}{*}{ Locality } & Female & 206 & $100 \%$ \\
\hline \multirow{3}{*}{ Educational Qualification } & Urban & 125 & $60.9 \%$ \\
\cline { 2 - 4 } & Rural & 81 & $39.1 \%$ \\
\cline { 2 - 4 } & BS & 116 & $56.7 \%$ \\
\cline { 2 - 4 } Professional Qualification & M.Phil & 55 & $27.2 \%$ \\
\cline { 2 - 4 } & JDPE & 35 & $16.1 \%$ \\
\cline { 2 - 4 } & B.ED & 08 & $3.88 \%$ \\
\cline { 2 - 4 } & None & 56 & $27.1 \%$ \\
\hline \multirow{2}{*}{ Age } & 18 to 20 years & 142 & $68.9 \%$ \\
\cline { 2 - 4 } & & 145 & $70.3 \%$ \\
\cline { 2 - 4 } & 21 to 25 years & 55 & $26.6 \%$ \\
\cline { 2 - 4 } & & & $\mathbf{1 0 0 . 0 \%}$ \\
\hline
\end{tabular}

Table 1 shows that the total number of respondents in this study was 206. In this table, 206 (100\%) were female respondents. In the same table, the total rural participants in the study were $81(39.1 \%)$ and the rest were urban respondents which were $125(60.9 \%)$. The above table also indicates the Educational Qualification of the respondents. Total BS respondents were $116(56.7 \%)$, MA/MSC respondents were $55(27.2 \%)$ and M.Phil respondents were $35(16.1 \%)$. Additionally, this Table 08(3.88\%), B.ED degree holders were $56(27.1 \%)$, whereas $142(68.9 \%)$ respondents were not anyone who have not any type of professional degree. The same table shows the percentages of the age of the respondents of the study. The total respondents who have aged from 18-20 years were 145 (70.3\%), 21-25 years were 55 $(26.6 \%)$ and more than 25 years were $6(2.9 \%)$.

$\mathbf{H}_{1}$ : Religious factors are significantly and positively associated with girls' participation in sports.

Table 2: Correlations Matrix

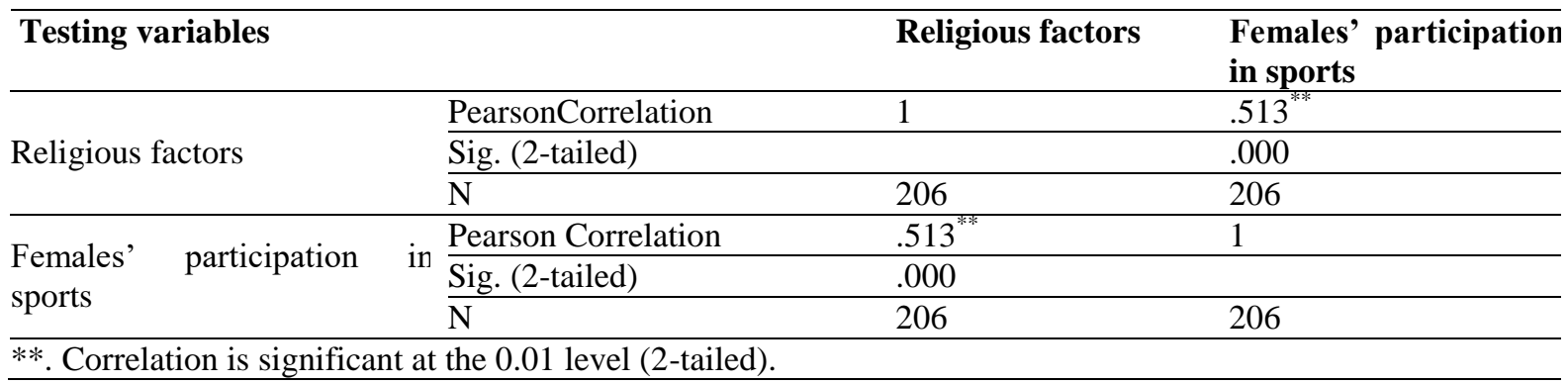

Hypothesis \# 2 was about the correlation between Religious factors and Females' participation in sports at the university level. The results show that the predictor is closely related to the main variable. Religious factors are also closely 
associated with Females' participation in sports (.513) Hence the results affirmed the relationship between Religious factors and Females' participation in sports. In the circumstances, H1 is accepted.

$\mathbf{H}_{1}$ : Socio-Cultural factors are significantly associated with girls' participation in sports.

Table 3: Correlations Matrix

\begin{tabular}{lccc}
\hline Testing variables & Socio-Cultural factors & $\begin{array}{c}\text { Females' } \\
\text { participation in } \\
\text { sports }\end{array}$ \\
\hline \multirow{2}{*}{ Socio-Cultural factors } & Pearson Correlation & $.448^{* *}$ \\
\cline { 2 - 3 } & Sig. (2-tailed) & 1 & .000 \\
\cline { 2 - 4 } Females' participation in sports & $\mathrm{N}$ & 206 & 206 \\
\cline { 2 - 4 } & Pearson Correlation & $.448^{* *}$ & 200 \\
\cline { 2 - 4 } & Sig. (2-tailed) & .000 & \\
\hline
\end{tabular}

Hypothesis \# 01 was also about the correlation between Socio-Cultural factors and Females' participation in sports at the university level. The results show that the predictor is significantly associated with the criterion variable. A SocioCultural factor is highly correlated with Females' participation in sports (.448). Therefore, results confirmed the existence of an association between Socio-Cultural factors and Females' participation in sports. Therefore, the H1 is substantiated and accepted as true.

$\mathrm{H}_{1}$. The religious factor will have a significant influence upon girls' participation in sports among Gomal University students.

Table 4: Regression analysis

\begin{tabular}{ccccccc}
\hline IV & $\mathbf{R}$ & $\mathbf{R}^{2}$ & $\mathbf{B}$ & Std. Error & $\mathbf{F}$ & Sig \\
\hline Religious factor & .750 & .692 & .580 & .083 & 15.21 & .000 \\
\hline
\end{tabular}

Dependent variable: Girls' participation in sports.

Table 4 is showing the regression output about the influence of Religious factors upon girls' participation in sports. The table depicts that $\mathrm{R}^{2}=.692$ which is indicating that $69 \%$ of the variance in Girls' participation in sports is explained by Religious factors. The Beta value (-.580) is showing that if there is one unit increase in the independent variable then .58 unit increases independent variable Girls' participation in sports. The $\mathrm{P}=.000<.05$ shows that the alternate hypothesis $\left(\mathrm{H}_{1}\right)$ is accepted.

$\mathbf{H}_{1}$ : Socio-Cultural factors will have a significant influence upon girls' participation in sports among Gomal University students.

Table 5: Assessment of the second hypothesis

\begin{tabular}{lllllll}
\hline IV & $\mathbf{R}$ & $\mathbf{R}^{\mathbf{2}}$ & $\mathbf{B}$ & Std. Error & $\mathbf{F}$ & Sig \\
\hline Socio-Cultural factor & .721 & .517 & .473 & .087 & 14.68 & .000 \\
\hline
\end{tabular}

Dependent variable: Girls’ participation in sports.

Table 5 is showing the regression output about the influence of the Socio-Cultural factor upon girls' participation in sports. The table depicts that $\mathrm{R}^{2}=.517$ which is indicating that $52 \%$ of the variance in Girls' participation in sports is explained by the Socio-Cultural factor. The Beta value (.473) is showing that if there is one unit increase in the independent variable then .47 unit increases the independent variable Girls' participation in sports. The $\mathrm{P}=.000<.05$ which shows that the alternate hypothesis $\left(\mathrm{H}_{2}\right)$ is accepted.

\section{DISCUSSION}

Findings of the present study have revealed that girls' students of the university are confronted mainly to socio-cultural, economic, religious as well as family factors. Islamic teachings do not allow the female to expose objectionable (sensitive) parts of their bodies in front of others concerning their participation in sports (Lenneis and Pfister, 2017). The non-availability and cost of the proper facilities and infrastructure also hinder their way to participation in sports. The findings of the present study corroborate with the findings of the studies conducted by Dinham (2017), who has confirmed the correlation between the cultural influence and its negative impact upon girls' participation in sports activities. The author has argued that, culturally, female involvement in sports activities is assumed to threaten the future wifehood of the girls.

In addition to that, the overall trend in the society, religious as well as traditional limitations also prevent girls' participation in sports (Dinham 2017). Another common notion of the masses is that as stated earlier, the non-availability 
of proper enclosed playing spaces and qualified female officials for organizing the girls' sports competition has also been one of the main issues in this regard. The majority of the Muslim parents are deeply concerned with the factor of covered and enclosed playing space and they avoid allowing their daughter to play in an environment that doesn't fall in conformity with their religious faith (Lenneis and Pfister, 2017). In traditional Muslim communities, there exists a common understanding among the masses that female involvement in sports fall outside the norms and values of the society (MOENT. 2017). The question of the association between participation in sports and its influence upon the femininity of participants has also been a point of concern for the male folk. It is presumed that participation in sports lessens female's attraction and it is most likely to turn their appearance and features like that of males. However, this type of male contention is turned down by McCormack, Nettel-Aguirre, Hawe, \& Doyle-Baker (2017) who have confirmed that the effect upon female features has directly been associated with the hormonal changes in the body of females, not by participation in sports or anything else. The present study has affirmed that the parental role plays a very positive and encouraging role particularly in connection with girls' participation in sports and this finding is endorsed by Ashraf (2019) who claims that parental attitude has a very positive influence on girls' participation in sports.

\section{CONCLUSIONS}

The findings of the study have revealed that religious, socio-cultural, and economic factors, as well as family issues, pose main barriers concerning participation in sports for the girl students' of Gomal University. Keeping in view findings of the present study it is concluded that religious restrictions, socio-cultural factors such as the tradition of the family, parental attitude, and so on are the prominent compelling factors affecting girls' participation in sports. Given the foregoing, it is recommended that religious leaders and parents and nobles of the society should show positive attitudes towards female participation in sports by paying to favor attention in connection with addressing the hazards occurring or likely to hinder the female participation in sports including religion, social restrictions, customs of the society, cultural beliefs and misunderstanding of the masses in the society. Educational institutions should highlight the actual state of affairs and educate the parents and common masses to support female participation in sports.

\section{LIMITATIONS}

This research study was conducted with the objective to determine the religious and socio-cultural factors affecting participation of girls in sports activities at university level. Population of this study comprised university girls students. Following were the main limitations of this research study:

1. The study was limited to only religious and socio-cultural factors affecting participation of girls in sports activities at university level. This can be extended to other prominent factors like financial, administrative as well as demographical aspects in terms of rural and urban communities.

2. Similarly this study was limited only to the girls' university students and their sports participation related issues were evaluated. However, issues of male university students can be evaluated in this type of research study.

3. The study setting was confined only to Gomal University Dera Ismail Khan and it can be extended to another public sector and private sector universities in the province.

4. Only two factors affecting girls sports participation in Gomal University Dera Ismail Khan were examined in this study, a comparative studies of different universities and gender based comparison of the sports participation related issues can be carried out in this regard.

\section{AUTHOR'S CONTRIUTION}

Professor Dr. Mohibullah Khan Marwat was the principal and corresponding author of the research study. Initiative of the conduct of this type of research study was the innate quest of the author. The role of the author in this research study had been pioneer to locate the problem and specify the area for the conduct of this work.

Dr. Afshan Jabeen extended helping hands throughout the conduct of this research study. Her role has been quite supportive and positive in the completion of this study. She had been committed for the review of the literature and arranging the related material.

Ismat Ullah also had been one of the key contributors in this particular research study. In addition to helping in the collection of data he was very supportive in the tabulation and analysis of data as well. Analysis of the greatly rely upon his expertise.

Muhammad Shah was the key contributor and responsible for the collection of relevant data. He devised the tool for the collection of data, administered it and distributed among the respondents. Interaction with the respondents was his main responsibility which he did with the best of his potentialities.

Sofia Saba also extended helpful hands in the completion of this research study. She had been assigned the task of arranging the tables, findings, discussion and conclusions. I admire her role as she had been very competent if this area of research. 


\section{REFERENCES}

1. Umaima, A.R. (2017). Sharoon Lost His Life Due to His Faith. The Nation. September 7. Available online: https://nation.com.pk/07-Sep-2017/sharoon-lost-his-life- due-to-his-faith

2. Al-Hassani, Salim (Spring 2012). A 1000 Years Amnesia: Sports in Muslim Heritage. MuslimHeritage.com. Foundation for Science, Technology, and Civilisation. Retrieved 30 June 2015.

3. Ashraf, M. A., and S. M. Tsegay. (2016). Analysis of globalization and "Englishization" in Pakistan. IJRSLL International Journal of Research Studies in Language Learning, 5(1), 79-88. https://doi.org/10.5861/ijrs $\underline{11.2015 .1205}$

4. Ashraf, Muhammad Azeem. (2018). Islamized Ideologies in the Pakistani Education System: The Need for Religious Literacy. Religious Education, 113, 3-13. https://doi.org/10.1080/00344087.2017.1384971

5. Ashraf, Muhammad Azeem. (2019). Exploring the Potential of Religious Literacy in Pakistani Education. Religions, 10, 429. https://doi.org/10.3390/rel10070429

6. Culpepper and Chuck, (2016). Muslim female athletes find sport so essential they compete while covered. The Washington Post.

7. Dinham, A, and Shaw, M. (2017). Religious Literacy through Religious Education: The Future of Teaching and Learning about Religion and Belief. Religions, 8, 119. https://doi.org/10.3390/rel8070119

8. Dishman, R. K., Saunders, R. P., Dowda, M., \& Pate, R. R. (2017). Perceptions of physical and social environment variables and self-efficacy as correlates of selfreported physical activity among adolescent girls. Journal of Pediatric Psychology, 32(1), 6-12. https://doi.org/10.1093/jpepsy/js1001

9. Harvard, Sarah (2016). Meet these 14 incredible Muslim women athletes who won medals at the 2016 Rio Olympics. MIC The Economist. Retrieved 29 December 2016.

10. Harvey, J. (2019). Using a Socioecological Approach to Examine Participation in Sport and Physical Activity Among Rural Adolescent Girls. Journal-Qualitative Health Research, 20(3), 150-180.

11. Heaney, C. A., \& Israel, B. A. (2018). Social networks and social support. In K. Glanz, B. K. Rimer, \& K. Viswanath (Eds.), Health behavior and health education: Theory, research and practice (4th ed.). San Francisco, CA: Jossey-Bass.

12. International Olympic Committee (IOC). Statistic [Internet]. (2019). International Olympic Committee; 2019 [cited 2019 Jun 20]. Available from https://www.olympic.org/women-in-sport/background/statistics

13. Qaiser, J. (2016). The Experience of Minorities under Pakistans Blasphemy Laws. Islam and Christian-Muslim Relations, 27, 95-115. https://doi.org/10.1080/09596410.2015.1108639

14. Kara, F, and Ali, D. (2010). An assessment of outdoor recreational behaviors and references of the residents in Istanbul. Scientific Research and Essays, 5, 93-104.

15. Verena, L. and Pfister, G. (2017). When girls have no opportunities and women have neither time nor energy: The participation of Muslim female cleaners in recreational physical activity. Sport in Society, 20, 1203-1222. https://doi.org/10.1080/17430437.2016.1269085

16. Lubans, D. R., \& Sylva, K. (2019). Mediators of change following a senior school physical activity intervention. Journal of Science and Medicine in Sport, 12(1), 134-140. https://doi.org/10.1016/j.jsams.2007.08.013

17. McCormack, G. R., Nettel-Aguirre, A., Hawe, P., \& Doyle-Baker, P. K. (2017). Friendship networks and physical activity and sedentary behavior among youth: a systematized review. International Journal of Behavioral Nutrition and Physical Activity, 10(1), 130. https://doi.org/10.1186/1479-5868-10-130

18. MOENT. (2017). National Education Policy 2017-2025; Islamabad: Ministry of Federal Education and Professional Training Government of Pakistan.

19. Muthuri S., Wachira, L., Onywera, V. \& Tremblay, M. (2019). Comparative study of physical activity patterns among school children in Kenya and Canada: Results from the ISCOLE Project. African Journal for Physical, Health Education, Recreation and Dance (AJPHERD), 20(2), 765-779.

20. Okonkwor, Oby C.N. (2011). Gender Bias in Women Participation in Sport: A serious setback to full emancipation of the Igbo race in Alohas Nwauwa (ed) "Ofo", ISA publication Washington, DC, USA.

21. Johnston, P. (2016). Kimia Alizadeh Zenoorin Becomes The First Iranian Woman To Win An Olympic Medal. Reuters/Huffington Post.

22. Rizvi A. and Rio (2016). History of Emirati female participation at the Olympic Games [Internet]. The National; 2016 July 31 [cited 2019 Jun 20]. Available from https://www.thenational.ae/sport/rio-2016-historyof-emirati-female-participation-at-the-Olympic-games-1.166001

\section{QUESTIONNAIRE}

Name

Age

Class

Department

Employment Status
Rural/Urban

Marital Status

Discipline

Faculty

Permanent/Temporary 
Game

Any Distinction
Participation Level

Level of Distinction

Please mark the appropriate option offered in front of each statement;

SCORE: $A=$ (5) $B=$ (4) $C=$ (3) $D=$ (2) $E=$ (1)

\begin{tabular}{|c|c|c|c|c|c|c|}
\hline SNo. & STATEMENT & $\begin{array}{l}\text { Strongly } \\
\text { Agree }\end{array}$ & Agree & Undecided & Disagree & $\begin{array}{c}\text { Strongly } \\
\text { Disagree }\end{array}$ \\
\hline 1 & $\begin{array}{l}\text { Your family support you to participate in the } \\
\text { sports }\end{array}$ & & & & & \\
\hline 2 & $\begin{array}{l}\text { Your parents encourage you to participate in } \\
\text { sports }\end{array}$ & & & & & \\
\hline 3 & Your parents don't allow you to participate & & & & & \\
\hline 4 & Your family remain neutral in this regard & & & & & \\
\hline 5 & $\begin{array}{l}\text { The role of your family is in favor of female } \\
\text { participation in sports }\end{array}$ & & & & & \\
\hline 6 & $\begin{array}{l}\text { Your parents have limited financial resources to } \\
\text { support you. }\end{array}$ & & & & & \\
\hline 7 & Your parents extend financial support to you & & & & & \\
\hline 8 & $\begin{array}{l}\text { Your parents do not extend financial support to } \\
\text { you }\end{array}$ & & & & & \\
\hline 9 & $\begin{array}{l}\text { Your parents arrange sports equipment for you } \\
\text { to participate in sports }\end{array}$ & & & & & \\
\hline 10 & $\begin{array}{l}\text { Did you satisfy the role of your parents } \\
\text { regarding your participation in sports? }\end{array}$ & & & & & \\
\hline 11 & $\begin{array}{l}\text { Your community is in favor of girl's } \\
\text { participation in sports. }\end{array}$ & & & & & \\
\hline 12 & $\begin{array}{l}\text { Girl's participation in sports is considered to be } \\
\text { un-social in your community. }\end{array}$ & & & & & \\
\hline 13 & $\begin{array}{l}\text { Girl's participation in sports is considered to } \\
\text { affect girl's femininity in their future life. }\end{array}$ & & & & & \\
\hline 14 & $\begin{array}{l}\text { Girl's participation in sports is considered to be } \\
\text { against the norms of Muslim society. }\end{array}$ & & & & & \\
\hline 15 & $\begin{array}{l}\text { Girl's participation in sports is considered to be } \\
\text { unethical. }\end{array}$ & & & & & \\
\hline 16 & $\begin{array}{l}\text { Girl's participation in sports leads to establish a } \\
\text { free society. }\end{array}$ & & & & & \\
\hline 17 & $\begin{array}{l}\text { Girl's participation in sports is un-Islamic } \\
\text { activity. }\end{array}$ & & & & & \\
\hline 18 & $\begin{array}{l}\text { Girl's participation in sports is considered to be } \\
\text { beyond Islamic practices. }\end{array}$ & & & & & \\
\hline 19 & $\begin{array}{l}\text { Girl's participation in sports is against the spirit } \\
\text { of Islam. }\end{array}$ & & & & & \\
\hline 20 & $\begin{array}{l}\text { Girl's participation in sports is a negation of the } \\
\text { Islamic teachings. }\end{array}$ & & & & & \\
\hline 21 & $\begin{array}{l}\text { Girl's participation in sports is a violation of the } \\
\text { Islamic principles framed for female sanctity } \\
\text { and privacy. }\end{array}$ & & & & & \\
\hline 22 & $\begin{array}{l}\text { Girl's participation in sports is not accepted in } \\
\text { Islamic communities. }\end{array}$ & & & & & \\
\hline 23 & $\begin{array}{l}\text { Girl's participation in sports has no place in } \\
\text { Islamic teachings. }\end{array}$ & & & & & \\
\hline 24 & $\begin{array}{l}\text { Girl's participation in sports is affected the } \\
\text { Islamic way of life. }\end{array}$ & & & & & \\
\hline
\end{tabular}

